This item was submitted to Loughborough's Research Repository by the author.

Items in Figshare are protected by copyright, with all rights reserved, unless otherwise indicated.

\title{
Complexity in decision making: Determining university library opening hours.
}

\section{PLEASE CITE THE PUBLISHED VERSION}

https://doi.org/10.1177/0961000617726127

\section{PUBLISHER}

(c) The authors. Published by SAGE Journals

\section{VERSION}

AM (Accepted Manuscript)

\section{PUBLISHER STATEMENT}

This work is made available according to the conditions of the Creative Commons Attribution-NonCommercialNoDerivatives 4.0 International (CC BY-NC-ND 4.0) licence. Full details of this licence are available at: https://creativecommons.org/licenses/by-nc-nd/4.0/

\section{LICENCE}

CC BY-NC-ND 4.0

\section{REPOSITORY RECORD}

Ravenwood, Jonlyn Clare, Graham Walton, and Derek Stephens. 2019. "Complexity in Decision Making: Determining University Library Opening Hours.”. figshare. https://hdl.handle.net/2134/25699. 


\section{Complexity in decision making: Determining university library opening hours}

\section{Abstract}

Making decisions on academic library opening hours is complex with many pressures on managers. This research surveys senior academic library managers from the UK, using a questionnaire to reveal views on library opening hours, the decision making process, and the pressures which influenced their decisions. A variety of factors were found, in particular satisfying undergraduate demands. The research also revealed the sources of information important in making decisions on opening hours and the influence of 'political' issues in the decision making process. Some institutions remove complexity by utilising $24 / 7$ opening, though this is not an option for many.

\section{Keywords}

Academic libraries, library opening hours, 24 hour opening, library decision making.

\section{Introduction}

University library managers need to take account of a range of factors and respond to a number of pressures when making decisions about their library. University libraries have had to respond to change and developments in UK government policy, society and technology which have impacted on the higher education 
sector. Current trends in learning and teaching mean that traditional teaching centred models where good teaching equates with passing of knowledge have been superseded by conceptualisations of teaching and learning where the emphasis is more on construction of knowledge (Carnell 2007; Jamieson 2013). Alongside the changes in pedagogy, the influence of Information and Communication Technologies (ICT) in higher education learning and teaching is also significant. Changes in technology have had a great impact; a rapid growth in the use of digital technology in teaching and learning is changing the way content is delivered and experienced (Beetham and White 2013). Emphasis is now on the student experience', involving not only teaching and learning but also other support services, including the library (Temple et al 2014). Questions have been raised about the relevance of library buildings: is the library space still needed by students (Rose 2009)? The role of the library as a 'gatekeeper' to information has changed, with information available in the Internet and through electronic resources, which students may not recognise as being supplied through the library. There is also the concept of an 'always on' culture of 24 hour access to information which the library has had to respond to in order to meet student expectations, which are high in terms of facilities available to them. For example Beetham and White (2013) 
investigated university students' expectations and experiences of ICT. They acknowledge that factors such as school experience, national culture and family background have an impact, but the majority of students now expect to have access to a range of learning spaces with robust Wi-Fi, storage facilities, desk space, power sockets and access to institutional devices alongside their own, especially desktop computers and printers, which may be delivered through the university library.

Therefore university libraries have had to adapt to an environment which has impacted on the ways library services are delivered and used. The numbers of students in the UK are large; latest figures from HESA (2016) show that in 2014-15 there were 2,266,075 undergraduate and postgraduate students in UK higher education. Within this context, an important decision that needs to be made is when the library should be open in order to meet the needs of diverse groups of users. This paper reports on a national survey of academic library managers which focused on the decision making process and factors that influence making decisions about library opening hours. This expands on work by Ravenwood, Stephens and Walton (2015), in which a regional workshop to explore potential 
influential factors was held. This research aimed to investigate both influential factors and in particular the decision making process in the academic library sector across the entire UK.

\section{Library opening hours and decision making}

Library opening hours have been increasing. In the USA and Canada, Laaker (2011) discovered that of the 66 Association of Research Libraries surveyed in her research, $91 \%$ offered 24 hour opening in some form. Data from the Times Higher Education World University Rankings indicates that the provision of 24 hour access in the UK is high in comparison to that many other countries; overall out of four hundred institutions $8.5 \%$ were found to have 24 hour, seven day a week access, but in the UK this figure rises to $24 \%$ (Reisz 2010). These findings contrast strongly with those from earlier studies, such as Steele and Walters (2001) and Arant and Benefiel (2002), where the latter evaluated ninety seven ARL libraries, finding that only $5.2 \%$ of these had a regular 24 hour schedule for access. Despite the proliferation of 24 hour opening, there is little investigation of library practices and decision making factors regarding opening hours in the UK. Much of the literature takes the form of case studies of academic libraries in the other countries, 
especially the USA (for example Engel, Womack and Ellis, 2002; Lawrence and Weber, 2012; Sewell, 2013). Whilst this is interesting and informative, the peculiarities of the UK higher education system means that influences and management strategies applicable in the USA are not necessarily as relevant to UK institutions.

For many years, the view has been expressed that the library is the centre of the university but now the ability to access services digitally anywhere challenges this assumption. In an influential discussion paper, Freeman (2005) argues that this central position can be re-claimed. The reason for this is that the library is the main building on a campus where the intellectual community can be found. But if it's all online why do students need the library building to be open? Pressure to change opening hours may be felt from the move to the use of eresources (Ipsos MORI 2009, p.12). The impact of technology which calls into question the need for a library as a physical space has been an issue since the 1990s and as Childs, Walton and Matthews (2013, p.6) point out, there are those who see the future of university libraries being in a physical space and those who envisage a continued move toward a virtual library offering. However evidence 
shows the demand for physical library space is still high (Childs, Walton and Matthews 2013, p.47). It is unclear how a university library is to meet this demand whilst still operating under not only ubiquitous institutional pressures but also pressure from changes in modes of access. Whether the library strategically sees itself as purely digital or hybrid, what is not questioned is that the 'major purpose of an academic library is to support the ...mission of its parent institution' (Moran 1992 p. 1157) and this still applies. With the main activities of universities being learning, teaching and research, the library needs to decide how best to support these. Many universities across the world have chosen to invest heavily in developing physical space; one trend is the creation of 'information commons' (Heitsch \& Holley 2011) which were developed first in the 1990s. The rationale for the information commons is to move library design away from storing books to be being focused on what the users need. However the importance attributed to 'library as place' is challenged by Ross and Senney (2008) who argue that the primary purpose of the library building is to be a storehouse. If this purpose is no longer paramount, then they question why the building should be labelled 'library' if print material is vanishing. Studies into the use of library space outside the 9.00am to $5.00 \mathrm{pm}$ pattern have found that students value the library as a quiet place to 
study during the night (Engel, Womack and Ellis 2001; Lawrence and Weber 2012;) rather than because of the resources it holds. The challenge for the library is, if they decide that physical library space is strategically important, how to configure it so it meets the needs of $21^{\text {st }}$ Century teachers, learners and researchers, and this includes providing appropriate library opening hours.

Library managers have to make decisions regarding the most suitable opening hours for their institution, taking account of factors such as managing libraries on shrinking budgets, but external sources of information to support these decisions are few. A small Canadian study (Koufogiannakis 2012) revealed types of information that librarians use in order to make decisions, which included not only quantitative data but also informal information from other librarians. This latter source of information also came to the fore in Ravenwood, Walton and Stephens 2015; respondents were clear that much of the benefit from the day for them came from hearing about the experiences of other library managers. This is in contrast to a study by Stenstrom (2015) who considered decision making practices within Canadian public libraries, where she found that the public library CEOs favoured objective, factual information when making decisions rather than recognising the 
importance of social interactions. This may have been because of a desire to be seen as making purely rational decisions.

A further source of information used in UK academic libraries is the National Student Survey, run every year online for final year undergraduate students at publically funded UK higher education institutions, where they give their opinions on aspects of their university, including the library. Current versions of the survey include a question with the wording 'The library resources and services are good enough for my needs' and participants are asked to mark their library out of five, where five is the highest mark. The results from this are used to inform library practice (for example Young 2011). The 2016 results show that $87 \%$ of students agreed with the question, indicating that students are satisfied in the main with their university libraries (SCONUL 2016). The wider results from the survey are used both to inform prospective students to help them make appropriate choices and it also acts as a driver to university enhancement (Callender, Ramsden and Griggs 2014). 
There are many complex and contradictory pressures on academic libraries which affect decisions by senior managers to provide access to library buildings for staff and students beyond 'normal' office style opening hours. There is a lack of guidance on how university libraries might make decisions on library opening hours, but understanding practices sector-wide is a step toward sharing best practice and improving decision making. The pressures and the process of decision making in UK academic libraries have up to now been little examined, an omission which this project aimed to address.

\section{Methodology}

Following on from a workshop held for university library decision makers in the East Midlands region, the next stage of the project was to survey library managers from the rest of the UK. An online self-completion survey was chosen as the most effective method of investigating the views and experiences of university library managers for a number of reasons. Firstly this method allows people in a wide geographic area to be questioned easily; as the survey was aimed at academic library mangers from across the UK and Ireland this was a prime consideration. Secondly it is time efficient for both the researchers and the participants. It allows 
participants to take part at a time convenient to them. It is a simple, quick and straightforward approach to gathering data (Bryman 2012, p.233). However it was recognised that there are drawbacks to this research design, most especially in terms of participation levels (Robson 2011, p.239). The questionnaire consisted of a number of short, closed questions and also questions inviting further comment. Two types of evidence collected in this stage of the research - quantitative from the survey and also qualitative comments which respondents were invited to make on the questions. This is in addition to the data gathered at the previous workshop; this three-pronged approach to gathering data strengthens the research. The questionnaire was designed to be relatively brief and not burdensome, but to question closely the relevance and accuracy of factors which may affect decision making for library opening hours that were suggested in the workshop, and to explore further aspects of decision making. It focused on assessing the form of influences on decision making, specifically asking questions about who makes the decisions, potential reasons for 24 hour opening and the influential factors that are taken into account when decisions are made. A small pilot exercise was carried out in order to test the ease of use and coherence of the questionnaire, from which minor changes were made. 
The population surveyed was a distinct group of senior library managers who are members of SCONUL which is an organisation that represents higher education libraries in the UK and Ireland and has 175 members. Access to potential participants is possible through specific mailing lists for that group; therefore participation by library managers was invited in this way. The response rate for the survey based on SCONUL membership was 34\%, with 60 completed questionnaires.

\section{Findings and discussion}

\section{Twenty four hour opening}

The overall picture of twenty four hour opening was complicated by different patterns of opening throughout the academic year and different patterns at multiple libraries within a University, reflecting findings from previous studies (Laaker 2011; Ravenwood, Stephens and Walton 2015). Forty five percent of respondents reported opening $24 / 7$ for at least part of the year, though only $11 \%$ had $24 / 7$ opening throughout the whole year. This is an increase on the figures from Reisz (2010), which indicated $24 \%$ of UK institutions had some form of $24 / 7$ opening. 
Most common were patterns of opening that varied by whether it was a period of peak use, such as semester or term time, or during exam or revision periods. A small number (6\%) explained that their libraries opened for 24 hours a day for five days a week, with shorter opening hours during the weekends and holidays. The patterns of opening were in some cases quite complex, though all respondents indicated that at least one of their libraries opened for more than twelve hours a day during term times, with the majority opening between 8.00am $-8.30 \mathrm{am}$ and closing between $9.00 \mathrm{pm}$ and midnight. During holidays, and for some libraries at weekends, the hours were reduced, often reflecting 'office hours', so between 9.00am -5.00pm for example.

The decision making process

Library opening hours are clearly an important strategic issue in academic libraries; $98.3 \%$ of respondents indicated that this is the case in their libraries. For such an important strategic issue it is surprising that little about opening hours was found in the review of the literature; this indicates that this research is both timely and needed. 
A question asked 'who is involved in deciding opening hours?' and respondents could choose a number of options or make their own comments. The results are shown in table 1:

Table 1

\begin{tabular}{|l|l|}
\hline Decision maker & $\begin{array}{l}\text { Percentage indicating these are } \\
\text { involved }\end{array}$ \\
\hline A senior library manager & $87 \%$ \\
\hline Senior university managers & $47 \%$ \\
\hline A library committee & $32 \%$ \\
\hline Security & $27 \%$ \\
\hline Facilities or buildings management & $25 \%$ \\
\hline Other & $37 \%$ \\
\hline
\end{tabular}

Unsurprisingly the majority (87\%) stated that a senior library manager was involved, but it was interesting to see the range of other stakeholders involved; it is clearly not only a library decision. The 'others' category included mainly students or 
student representatives, though it was not entirely clear if they were only consulted or were directly involved.

In previous research on library opening hours the participants were clear that they would welcome more evidence and better management information to support their decision making (Ravenwood, Stephens and Walton 2015). However in this survey it was less clear. This may be because the library managers were less candid in a survey rather than in a supportive safe environment of the workshop. However as table 2 shows, many different types of evidence were gathered by respondents to support their decision making and all mentioned gathering some type of evidence to support their decisions.

Table 2

\begin{tabular}{|l|l|}
\hline Type of evidence & $\begin{array}{l}\text { Percentage indicating they } \\
\text { gathered this type }\end{array}$ \\
\hline Feedback from the Student Union & $87 \%$ \\
\hline Ad-hoc feedback from users & $83 \%$ \\
\hline User surveys & $78 \%$ \\
\hline
\end{tabular}




\begin{tabular}{|l|l|}
\hline Occupancy figures & $77 \%$ \\
\hline Benchmarking against other & $73 \%$ \\
\hline The National Student Survey & $65 \%$ \\
\hline Other & $37 \%$ \\
\hline Evidence not gathered & $0 \%$ \\
\hline
\end{tabular}

Changes to timetables, evidence from internal student surveys or discussion groups, or from library staff were all cited in the comments. Also $73 \%$ said they used benchmarking against other universities as evidence in order to inform the decision making on opening hours. This reflects not only the importance of the library as part of the overall offering to the student but also the competitive higher education context in which library managers are working. Respondents indicated that comparisons were often made with local institutions and this was also found in the regional workshop phase of this research where it acted as a driver to participation. 


\section{Influential factors}

Table3 shows influential factors as ranked in order of importance by respondents.

The factors comprise of both user demand and operational issues. Unsurprisingly factors focused on services for undergraduate students are seen as the most important factors, even more so than costs or budgets. Demand from other users groups is much lower on the list, as are environmental factors.

Table 3

\begin{tabular}{|l|l|l|}
\hline Factor & rank & $\mathbf{N}=$ \\
\hline Demand from undergraduates & $=1$ & 60 \\
\hline Exam revision periods & $=1$ & 58 \\
\hline Maintaining appropriate opening hours across multiple & 3 & 41 \\
\hline site libraries & & $=4$ \\
\hline Demand from student union & $=4$ & 60 \\
\hline National Student Survey performance & $=4$ & 58 \\
\hline Expectations from full fees (the student experience) & $=7$ & 60 \\
\hline Cost constraints/budget & $=7$ & 60 \\
\hline Library as safe place & & 60 \\
\hline
\end{tabular}




\begin{tabular}{|l|l|l|}
\hline Providing security staff for the library & 9 & 60 \\
\hline Demand from postgraduates & $=10$ & 60 \\
\hline Estimated or actual 'take up' figures / evidence of use / & $=10$ & 60 \\
\hline $\begin{array}{l}\text { The library as part of the university offering (i.e. Viewing } \\
\text { the institution holistically) }\end{array}$ & $=10$ & 60 \\
\hline Security of users to and from the library & & \\
\hline Security of campus & $=10$ & 58 \\
\hline Demand from university management & $=14$ & 60 \\
\hline Providing standard patterns of opening & $=14$ & 60 \\
\hline Cleaning the library & 16 & 58 \\
\hline Effective university marketing & $=17$ & 60 \\
\hline The 24 hour culture & $=17$ & 60 \\
\hline Work-life balance for library users & $=17$ & 59 \\
\hline Effective library marketing & $=20$ & 59 \\
\hline Demand from researchers & $=20$ & 60 \\
\hline Physical characteristics of the library building & $=20$ & 59 \\
\hline Work-life balance for library staff & $=23$ \\
\hline
\end{tabular}




\begin{tabular}{|l|l|l|}
\hline Availability of transport to and from the library & 25 & 57 \\
\hline Limiting carbon footprint / environmental concerns & 26 & 60 \\
\hline Demand from academics & $=27$ & 60 \\
\hline Potential for inappropriate use of the library & $=27$ & 59 \\
\hline Preparing students for future working hours & 29 & 59 \\
\hline
\end{tabular}

A further series of questions asked the respondents to indicate how important demand from different user groups was in their decision making. This question was important as during the first phase of this research the workshop participants had indicated this was a particularly influential factor. Most of the factors revealed in this study reinforce the findings from the previous regional workshop based study by Ravenwood, Stephens and Walton (2015), highlighting the relevance of these findings to the academic library sector. 


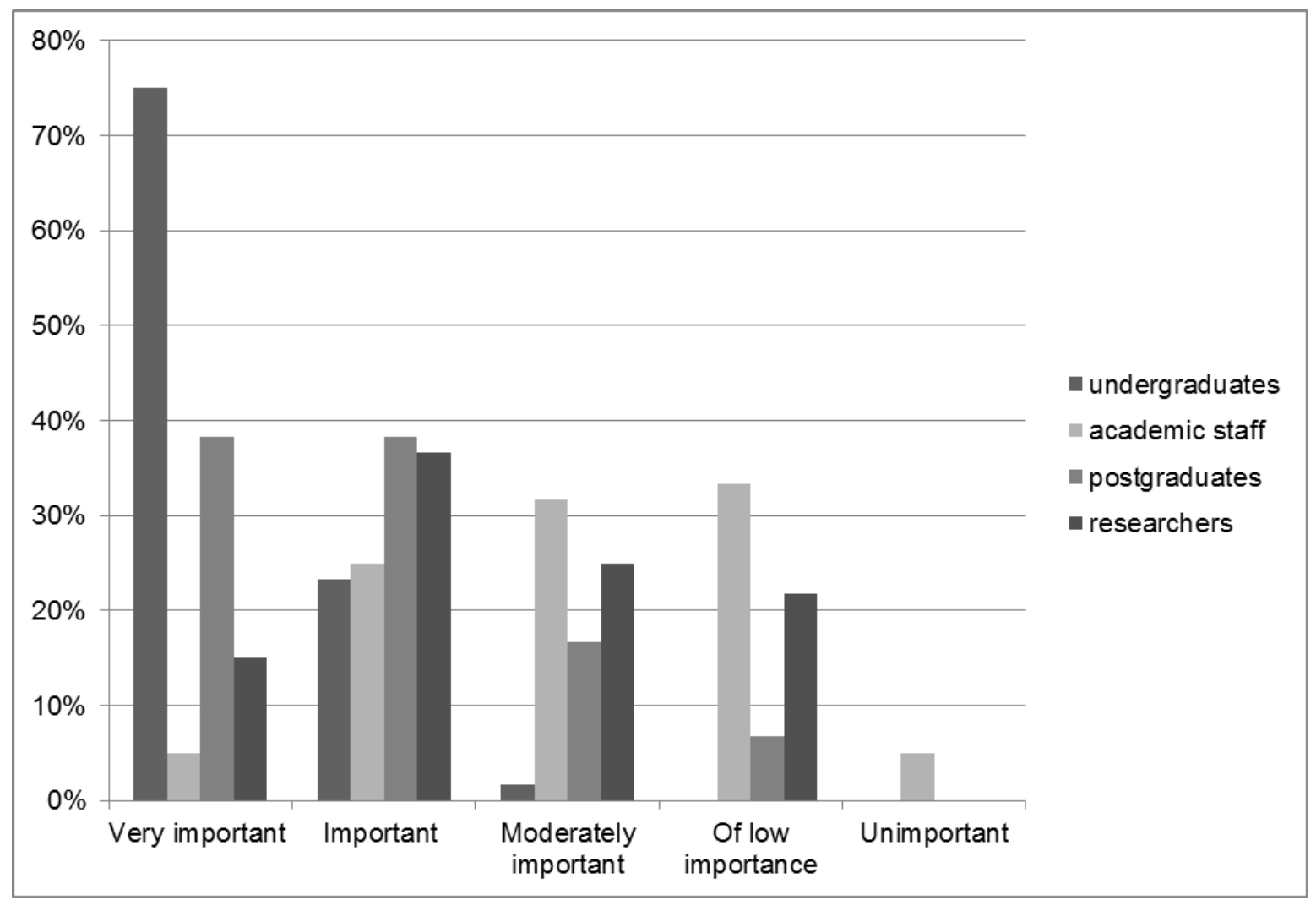

Unsurprisingly, demand from undergraduates was the most influential and this is further explored in the next section.

\section{User demand factors}

As is immediately clear from table 3 , the most important concern to the library managers surveyed is to satisfy undergraduate needs and this was emphasised in the comments supplied by respondents. Undergraduates are not only largest group 
of library users, but there are multiple channels for their demands to be made. They are able to voice their demands by responding directly to requests for feedback, through focus groups and internal student surveys, as well as the NSS. Students can also make their demands felt through their representatives on various committees and through the Student Union; as one respondent stated 'We review annually anyway, but our Student Union lobbies constantly for longer hours.'

Pressure is clearly felt by managers to pacify vociferous demand from students for longer opening hours, but this seems to be a simplification. Many respondents commented that they work with the Student's Union on the issue of opening hours; for example respondents stated that 'we regularly discuss opening hours with students', 'most recent increases are as a result of joint work between Library and Students Union' or 'discussions took place with the SU'. Libraries are keen to meet the demands of students as they are user-centred services; most gather feedback from students, that is then used as evidence for decisions.

Despite postgraduate student influence being clearly less than undergraduate influence, this is still a factor of some importance: 'Demand from postgraduates has had influence on vacation opening hours, because postgraduates see less of a 
distinction between 'term-time' and 'vacation', stated one respondent. Also there was recognition of the needs of international students, particularly postgraduates. Figures for $2014-2015$ show that $13 \%$ of undergraduate students and $38 \%$ of postgraduate students are from outside the UK (UK Universities 2016) and respondents indicate that they have a particular interest in using the library as a workspace.

There is a clear indication that institutional and library staff are concerned with the wellbeing of the students; some mention possible student welfare concerns of working throughout the night. The impact of student welfare concerns can result in a reduced pressure to open 24 hours, at least from the institution. Respondents recognise that students see the library as somewhere quiet and safe, as a respite from other university spaces or house mates; as one library manager put it 'If you talk to our students, they talk about the Library as 'place' - as such it is very important to them to have it available as long as possible as a respite from the other pressures of life'. However the duty of care was not limited to the library. Some universities have a campus and some are situated within an urban environment, and some have students that live at home. For the latter the provision 
of transport at night can be an issue; library managers clearly saw their duty of care to include transport home from the library. This raises questions about where the duty of care for students ends, who are after all young adults.

\section{Operational factors and decision making}

The previous workshop research indicated that security is an important factor in decision making, in terms of both the security of users and in providing security staff for the library buildings, particularly in unsocial hours. Many survey respondents explained that security is provided through external security companies or campus security, but not by the library. This helps to explain the finding that staff work life balance is only ranked $=23$ (along with 'physical characteristics of the library building'), as staff contracts have in the main not been changed but extra staff, often non-library or non-library professional, are employed during unsocial hours instead. Respondents differentiated between staffed service hours and the library building being opened, with many using self-service or bought in security or student staff to work out of day time working hours. In this way existing staff do not have to change their working hours but the library building is able to operate. Examination of the qualitative comments in the survey revealed differences within institutions between demands from different academic 
departments or between different library user groups. One method libraries have developed for managing this is to open $24 / 7$ so users have the choice of when to use the library; this decreases complexity both for users and for the library. Students find it easy to remember and so simplicity of the library offering is a desirable outcome of decision making of opening hours; $71.7 \%$ of respondents thought it important or very important to provide standard patterns of opening. However many libraries have an inconsistent pattern of opening based on historical decision making, which means that although students want more consistent opening hours this is not always possible due to cost.

The decision was felt to be complex by $48.3 \%$, whilst interestingly $43.3 \%$ felt that it was not. Those that did not agree that it is a complex decision in the main explained this by saying that because of student pressure or directives from senior University staff the decision was straightforward, although often acquiring the appropriate funding was not! Many reasons for added complexity in decision making were mentioned in terms of extra factors to be taken into consideration, which echo responses to later questions. Extra factors that increase complexity in particular include: 
- having more than one library to consider, which two thirds of the respondents have

- the desire to have consistency in opening hours across sites, although this is not always possible

- high demand from students for 24 hour opening without corresponding occupancy levels - students are seen as liking the principle of $24 / 7$ without commitment to use facilities in this way

- the library as a place, or space, where students can use the library as an escape from noisy living spaces

- the needs of international students, though the reasons for this are not always made clear in the survey

- concern for the welfare of students

- the public relations benefit of longer opening hours.

Related to this is the issue of reviewing opening hours. The majority of libraries reviewed their opening hours, with $76.4 \%$ reviewing them in the last year, often on a 'continuous' or at least a regular basis. Reviews were overwhelmingly prompted by feedback from students, although pressure from budgets, benchmarking against 
other universities, prompts from senior university figures and changes to the university calendar or strategy were all mentioned. The respondents that reported not reviewing their hours said the reason for this was because they were satisfied with them as they are; these five institutions all have extensive opening hours already, with $24 / 7$ opening for at least part of the year. The respondents were also asked whether they thought there is pressure to have the university library (or libraries) open $24 / 7$ all year round and $73.3 \%$ either agreed or strongly agreed. In contrast $20 \%$ either disagreed or strongly disagreed and these were institutions that already have extensive opening hours. This indicates that the way forward for many institutions to deal with the pressure and to reduce complexity is to open at least $24 / 7$ for part of the year; in this way pressure is lessened, stakeholders are potentially more satisfied and the complex nature of the decision is reduced.

However pressure to open and complex decision making needs to be balanced with economic considerations. Issues were raised in relation to costs in the survey, reflecting concerns found in the workshop stage of this research. In particular the need to make the best use of limited resources, such as not opening 24 hours over the summer months; the need to consider and demonstrate return on investment 
(ROI); and have evidence of the value for money of library expenditure. The changing funding landscape for HE in the UK of higher student fees leads to concerns about the expectations of students as consumers; as one respondent stated 'Funding is a block to extending opening hours further, however the current students view themselves as customers who have already paid for access.' The importance of costs as a factor in decision making was asked; $52 \%$ of respondents stated this was very important, with a further $38 \%$ indicating it was important. However, one respondent commented that twenty four hour opening demonstrates that the library is 'maximising the return on investment in learning materials, IT and space. Why would you spend money on resources then not provide access to them by closing the doors?'

\section{Library audiences}

There is an internal institutional audience to impress, including current students (and their parents), university management and rest of the university. Twenty four hour opening is seen to enhance the internal profile of the library to other services and departments and to demonstrate that libraries are maximising investment in buildings and resources. In addition there is an external audience that includes 
potential students and other comparable universities. Competitive advantage and comparison to other institutions is important, with 'The PR value of 24 hour opening is a significant factor' according to one respondent, with another stating that 'some opening hours are 'loss leaders' and are about PR'. Longer opening hours increases competitiveness in comparison to other universities; as one respondent commented, twenty four hour opening 'demonstrates commitment to the student experience and the importance of Libraries to their study.' Another respondent implied that there is value in students feeling that their university is 'as good as others', but there are issues here as it is difficult to compare between smaller or larger institutions for example. As one respondent stated 'We have the disadvantage of being a very small university but some students compare our opening hours with large universities and don't compare like-with-like.' However the library can impress parents and students by being seen to be addressing student demands proactively and to a greater extent than other comparable institutions. One manager commented 'I think there is a value to extended opening in that it shows we can match (as far as is practicable) what other university libraries offer and this has a psychological importance.' This also applies to prospective students; a reason suggested for twenty four hour opening included 'Recruitment - it is one 
of the most common questions parents ask and is (crudely) part of the 'price comparison'.

These findings indicate that there is a strong 'political' aspect to 24 hour opening; the desire to maximise investment in library services helps to justify that investment to the university. The library is unsurprisingly seen as part of the university offering, which creates an opportunity to position the library at the heart of the student experience and demonstrates its importance to university managers. There are covert benefits for the library that reach further than usage statistics are able to show and the library is able to demonstrate its value through implication.

\section{The library building and its environment}

It was clear from this survey that the library as a physical place is still very valuable to students, with respondents commenting extensively on the preference they see of their students for using the library as a safe workspace away from other pressures and distractions. This reflects findings in the literature, such as Childs, Walton and Matthews (2013). However if it is only the provision of a safe space that is of concern, then the library must be considered in combination with other 
physical spaces on campus. In addition, many of those with more than one library included comments indicating that only some of those libraries were opened 24/7. However few mentioned closing specific areas of the library buildings; this may be because this research did not explicitly explore this issue.

The environment as an influential factor in decisions making was ranked very low in comparison to other factors (see table 3). Comments from respondents included the recognition that although the 'green' agenda has been important, and some libraries are making improvements to buildings for example to contribute towards this, the expectations of students must be considered first; for example 'Our library service is strongly committed to 'green impact' but $24 / 7$ expectations will trump this.' It may be that environmental concerns can be addressed through other means, for example by refurbishing heating and lighting systems to be more energy efficient, rather than by not using them at all, although the evidence from this survey suggests that for some this may be difficult due to the construction or configuration of the building. As one respondent mentioned 'there is an increasing cultural drive for $24 \mathrm{hr}$ opening. Our library building makes it difficult to do so in an environmentally friendly way'. 


\section{Conclusions}

It is difficult to discover how library opening hours have changed over time and even harder to determine the causes of change. Decisions on library opening hours touch on many aspects of the role of the library, in particular fulfilling student expectations and positioning the library at the heart of the university in the perception of university management, students and their parents. The focus is very much on satisfying undergraduate students and there is a growing recognition of the importance of international students. As shown in this research, decision making can be complicated by a range of user and operational factors, such as the extent of exam periods or having multiple libraries in one institution, but the majority of libraries are providing some form of extended opening to satisfy the demands from undergraduates. The findings from this research link closely with previous research that demonstrate the complex picture of twenty four hour opening across the academic sector. Many libraries that offer twenty four hour opening do so for a limited period of time during the academic year and often provide only a limited library service, but there is variety in the patterns of provision. 
Whilst the need and desire to satisfy the demand from undergraduates is a straightforward issue, and these demands are clearly communicated through multiple channels, the complexity of decision making is in balancing this demand with operational factors, including justifying costs on the basis of actual usage. Some libraries have cut this 'Gordian knot' by introducing 24/7 opening all year round and thus removing the complexity completely, however for many libraries this is not yet a viable strategy. Cost is an important factor, in contrast to environmental concerns which are receding in importance, so there is a need to explore further the economics of library opening, which includes, but is not limited to, actual costs as well as intangible measures and return on investment.

\section{References}

Arant W and Benefiel C (2002) Hours of operation and service in academic libraries: toward a national standard. Public Services Quarterly 1(1): 71-85.

Beetham H and White D (2013) Students' expectations and experiences of the digital environment. JISC, London. Available at:

http://repository.jisc.ac.uk/5572/1/JR0006_STUDENTS_EXPECTATIONS_EXEC_ SUMMARY_v2.pdf (accessed 12 December 2016). 
Bryman A (2012) Social research methods. 4th ed. Oxford: Oxford University Press.

Callender C, Ramsden P and Griggs J (2014) Review of the National Student Survey. London: NatCen. Available at:

http://www.hefce.ac.uk/media/hefce/content/pubs/indirreports/2014/Review, of,the, NSS/2014 nssreview.pdf (accessed 12 December 2016).

Carnell E (2007) Conceptions of effective teaching in higher education: extending the boundaries. Teaching in Higher Education 12:1: 25-40 Childs S, Matthews G and Walton G (2013) Space in the University Library - An Introduction. In: Matthews, G and Walton G (eds) University Libraries and Space in the Digital World. Farnham: Ashgate, pp.1-18.

Engel D, Womack K and Ellis U (2001) Opening a library 24 hours. Journal of Library Administration 36(4): 95-108.

Freeman GT (2005) The Library as Place: Changes in Learning, Patterns

Collections, Technology and Use. Available

at: www.clir.org/pubs/reports/pub129/freeman.html (accessed 14 December 2016). 
Heitsch EK and Holley RP (2011) The information and learning commons: some reflections. New Review of Academic Librarianship 17(1): 64 - 77.

HESA (2016) Students and graduates. Available at: https://www.hesa.ac.uk/dataand-analysis/students (accessed 03 January 2017).

Ipsos MORI (2009) The impact of the economic recession on university library and IT services. Available at:

http://www.webarchive.org.uk/wayback/archive/20140615233306/http://www.jisc.ac .uk/media/documents/publications/libsitimpacts.pdf (accessed 12 December 2016). Jamieson P (2013) Reimagining Space for Learning in the University Library. In: Matthews $\mathrm{G}$ and Walton $\mathrm{G}$ (eds) University Libraries and Space in the Digital World.. Farnham: Ashgate, pp.141-154.

Koufogiannakis D (2012) Academic Librarians' Conception and Use of Evidence Sources in Practice. Evidence Based Library and Information Practice 7(4): 5-24. Laaker S (2011) Keeping the doors open: Exploring 24-hour library access at Washington University in St. Louis. Research Library Issues 277: 15-25. Lawrence $P$ and Weber $L$ (2012) Midnight-2.00 a.m.: what goes on at the library? New Library World 113 (11/12): 528-548. 
Moran BB (1992) University Library. In: Clark BR and Neave GR (eds) The Encyclopedia of Higher Education Volume 2: analytical perspectives. Pergamon Press: Oxford, pp. $1156-1163$.

Ravenwood C, Stephens D and Walton G (2015) Establishing influential decision making factors for University library opening hours: an exploratory UK regional study. New Review of Academic Librarianship 21(1): 52-67.

Reisz M (2010) You want to go to the library at 3am? Britain's the place. Times Higher Education, 9 September, no page.

Robson C (2011) Real World Research $3^{\text {rd }}$ ed. Chichester: John Wiley \& Sons Itd. Rose S (2009) Student views on library services: key lessons for developing libraries of the future. SCONUL Focus 47: 4-6.

Ross L and Senney P (2008) The library is dead, long live the library! The practice of academic librarianship and the digital revolution. Journal of Academic Librarianship 34(2): 145 - 152.

SCONUL (2016) National Student Survey (NSS) Data. Available at:

http://www.sconul.ac.uk/page/national-student-survey-nss-data (accessed 12 December 2016). 
Sewell B (2013) 24-Hour Access: Responding to Students' Need for Late Library Hours at the University of Denver. Journal of Access Services 10(1): 14-27. Steele P and Walters C (2001) Extended Library Hours: A SPEC Kit. Washington: The Association of Research Libraries.

Stenstrom C (2015) Decision-making experiences of public library CEOs A study exploring the roles of interpersonal influence and evidence in everyday practice. Library Management 36(8/9): $644-652$.

Temple P, Callender C, Grove L and Kersh N (2014) Managing the student experience in a shifting higher education landscape. York: The Higher Education Academy.

Young D (2011) Student expectations and the NSS: action planning at Northumbria University Library: a case study. SCONUL Focus 52: 9-10.

Universities UK (2016) Higher Education in facts and figures 2016. Available at: http://www.universitiesuk.ac.uk/facts-and-stats/data-and-analysis/Pages/facts-andfigures-2016.aspx (accessed 03 January 2017). 